\title{
O Sindicato das Proteínas
}

\section{DaVid MarÇaL *}

\begin{abstract}
A história que aqui apresento não é um relato sistemático, apenas uma colecção de marcos que considero significativos e que contêm informação acerca das várias técnicas e áreas que percorri, num doutoramento que teve como abordagem central a cristalografia de raios-X de proteínas. A cristalografia de raios-X é uma técnica que esteve no cerne da atribuição de vários prémios Nobel e que permitiu ao longo dos últimos 50 anos obter conhecimento inestimável acerca do modo como funcionam os seres vivos.
\end{abstract}

$\mathrm{Na}$ célula, as proteínas estão envolvidas em quase todas as actividades. Há proteínas que têm uma função estrutural, ou seja são usadas como tijolos para construir uma estrutura da célula, por exemplo uma "cauda" que Ihe confere mobilidade ou um poro por onde entram e saem iões. Podem servir de autocarro para moléculas que andam de um lado para o outro, como é o caso da hemoglobina que transporta oxigénio nas células do sangue. Podem também funcionar como catalisadores, possibilitando a ocorrência de reacções químicas no ambiente moderado da célula, que de outro modo precisariam de condições muito vigorosas para ocorrer em tempo útil. A este tipo de proteínas, que facilitam reacções químicas, chamam-se enzimas.

O que as enzimas fazem é orientar muito bem as moléculas envolvidas, criando nichos e ambientes controlados onde tudo seja mais fácil e provável. Há enzimas muito específicas, ou seja, que só servem para fazer uma coisa. Se o picador na imagem (Figura 1) fosse uma enzima, seria bastante inespecífica, pois serviria para picar todos os tipos de carne (e eventualmente outras coisas). Este instrumento, tal como as proteínas, tem várias peças. Nas proteínas as peças

Instituto de Medicina Molecular, Universidade de Lisboa

E-mail: david.marcal@gmail.com chamam-se domínios. E estas peças (domínios) existem em várias máquinas (proteínas) que tenham funções parecidas. Uma proteína homóloga de outro organismo seria um picador parecido com este. Quanto mais diferenças houvesse, maior seria a distância evolutiva entre os dois organismos. É natural que os picadores de dois mamíferos sejam mais parecidos do que o picador de um mamífero e o de uma alga. Uma coisa salta à vista: a forma que têm é importante para a função. Por onde se liga o substrato (carne inteira) e o produto da reacção (carne picada), como funciona o picador (mecanismo). E é isso que faço: determino a forma de proteínas em três dimensões, recorrendo a um conjunto de técnicas conhecidas como cristalografia de raios-X.

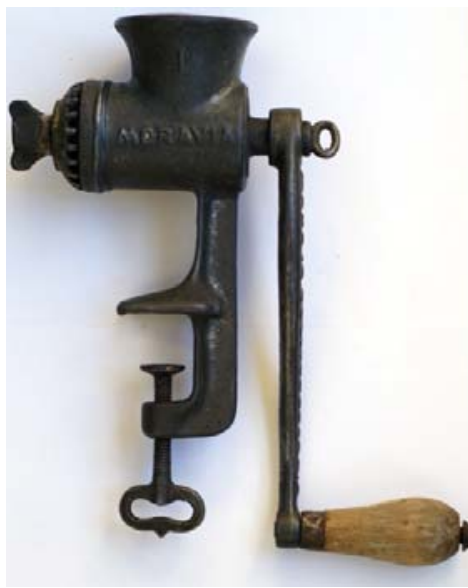

Figura 1 - Tal como o picador de carne, as proteínas podem ser constituídas por várias peças (domínios). Neste caso, há claramente um domínio de ligação a uma superfície plana de espessura variável, um local de ligação do substrato (carne) e um canal de saída do produto da reacção. Os restantes componentes também são essenciais ao funcionamento da enzima. Por exemplo, se obtivéssemos uma enzima que não tivesse a manivela, o substrato poderia ligar-se mas não ocorreria transformação do substrato 
outros. A alanina, outro aminoácido, escreve-se no ADN como GCC. Uma proteína tem um número variável de aminoácidos. As que eu estudo têm cerca de 300. Assim, no ADN estão codificadas em genes com cerca de 900 bases. No final, há um sinal para parar (TGA), que é como quem diz "o gene acaba aqui, não há mais aminoácidos para esta proteína”.

Por exemplo, a sequência de ADN:

\section{ATG - GGC - GCC - GGC - TGA}

Traduz-se por:

Começar - glicina - alanina - glicina - terminar

Claro que isto seria uma proteína com três aminoácidos. O que não é propriamente uma proteína. Mas a ideia é esta. E na realidade o sinal de começar também corresponde a um aminoácido, que é uma metionina. É a esta correspondência entre trios bases de ADN e aminoácidos que constituem proteínas que se chama código genético. Era precisamente isto que me levava a York. Fazer corte e costura com ADN. Uma actividade a que as pessoas normalmente chamam biologia molecular ou (mais em desuso) engenharia genética.

Estava interessado em proteínas de duas bactérias patogénicas: Campylobacter jejuni (diarreias) e Klebsiella pneumoniae (infecções hospitalares).

A ideia era "cortar" o ADN que codificava as proteínas em estudo e inserilo noutra bactéria mais conveniente para os cientistas, que se chama Escherichia coli (mas podem chamar-Ihe E. coli).

$\mathrm{Na}$ realidade não inserimos o $\mathrm{ADN}$ original, inserimos um cópia da parte (gene) que nos interessa. E depois fazemos com que o objectivo da vida dessas bactérias seja produzir essa proteína, que não é delas.

E assim se passavam os dias em York. Entre pipetas, tubinhos pequenos, tantos que não nos podíamos dar ao luxo de os numerar e apenas os conseguíamos identificar pela posição no suporte, numa lógica batalha naval. Começavam cedo, com um pe- queno almoço insano, um almoço frugal (em geral uma sandes de queijo com tomate), uma corrida para o jantar (a cantina fechava muito cedo) e terminava também cedo com uma pint num pub.

\section{As Bactérias que Trabalham Para Nós}

O modo como fazemos as bactérias trabalhar para nós, ou seja produzir uma proteína que não é delas e que não thes serve para nada, mas que nos interessa a nós, tem a sua inteligência e perversão.

A dada altura convencemo-las de que precisam mesmo muito de produzir a "nossa" proteína. Para isso, adicionamos ao meio de cultura (uma espécie de papa para bactérias) uma molécula que se parece muito com um derivado de um açúcar que elas gostam, a lactose. Isto faz com que a maquinaria genética da bactéria tome medidas para começar a produzir as proteínas necessárias para "digerir" a lactose. Só que não são essas que produzem.

Por artes de engenharia genética, no lugar delas no ADN está o gene da proteína que nos interessa a nós. As bactérias são assim, de algum modo, enganadas. Depois, o que acontece é que rebentamos com elas e tiramos a proteína lá de dentro. Felizmente ainda não há activistas dos direitos das bactérias (e ainda bem, caso contrário deixaríamos de poder tomar antibióticos e regressaríamos ao início do século passado).

Regressado de York, dediquei-me à produção biotecnológica de proteínas. O que trouxe na bagagem foram pequenos tubos, aparentemente vazios. Mas, com o olhar treinado e sob luz directa podiam distinguir-se resíduos esbranquiçados no fundo de cada tubo, que na realidade continha ADN liofilizado (o branco não é do ADN, mas sim de proteínas associadas).

Porções circulares de ADN, cada uma delas contendo um gene com a informação para construir uma proteína. Inserido esse ADN dentro das bactérias, e com a motivação adequada já descrita, elas estão dispostas a cola- borar. Fazemos com que o objectivo da vida delas seja produzir a proteína que queremos.

\section{Cristais e Outros Que Tais}

Não é fácil fazer cristais de proteína, porque as coisas têm tendência a existir de um modo desorganizado, e um cristal é uma forma da matéria em que as moléculas estão todas orientadas da mesma maneira e distribuídas a distâncias regulares pelas três dimensões do espaço. O principio é ter a proteína dissolvida e ir lentamente retirando a água. A proteína está dissolvida porque há moléculas de água que estabilizam as suas cargas de superfície. Quando as moléculas de água disponíveis escasseiam, as proteínas juntam-se umas às outras e acabam por passar ao estado sólido na forma de agregados. Em condições especiais, juntam-se de um modo organizado e formam uma rede, semeIhante a um painel de azulejos em três dimensões. Isso é um cristal. Como não sabemos à partida em que condições isto acontece experimentamos muitas coisas. Diferentes aditivos que competem pelas moléculas de água, concentrações de proteína, etc. Tantas que até temos robôs para ajudar.

Estas experiências são feitas em pequenas gotas, que evaporam muito lentamente num ambiente fechado. $\mathrm{O}$ resultado mais comum não é um cristal, mas sim um precipitado amorfo, sem utilidade para caracterização por raios-X. Quando finalmente encontramos condições em que a proteína cristaliza é quase como descobrir a combinação de um cofre.

\section{Os Electrões às Voltas na Rotun- DA COM As LUZES AcESAS}

Fui pela primeira vez a Grenoble (França) em 1999, no âmbito do meu estágio de licenciatura em cristalografia de raios- $X$ de proteínas. Um curso de três dias sobre aplicações de feixes de raios-X produzidos num sincrotrão. Um sincrotrão é um acelerador de partículas, um sítio onde os electrões (ou positrões) andam a velocidades próximas da luz. Um electrão às voltas num acelerador de partículas é como um carro às voltas numa rotunda com os faróis acesos: emite luz numa di- 


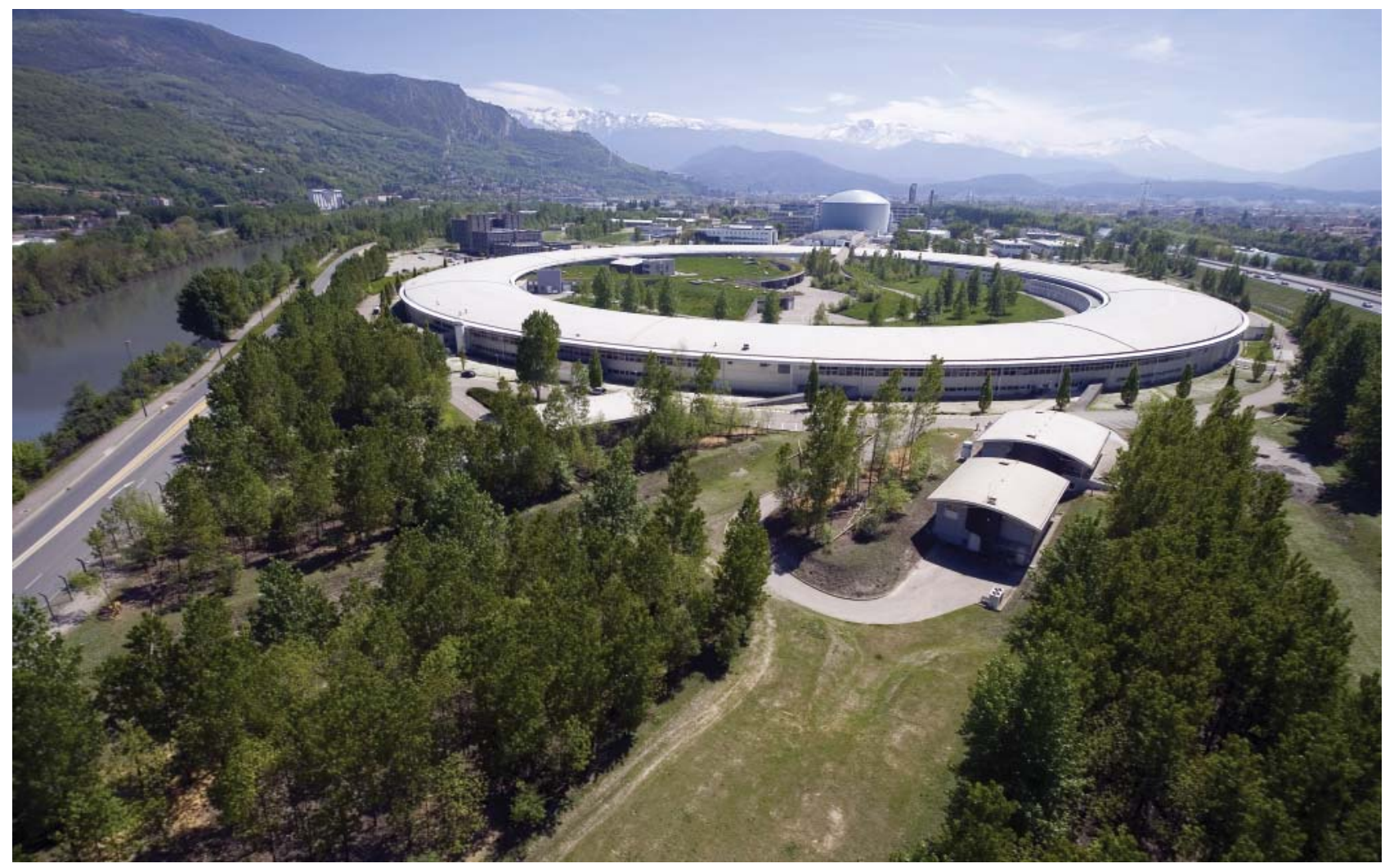

Figura 2 - Ao contrário de outros aceleradores de partículas, o ESRF não está enterrado e o túnel circular pode distinguir-se perfeitamente [Crédito: A. Petricola, AIR ISERE, ESRF]

recção tangencial à sua trajectória. No caso do carro às voltas na rotunda é luz visível, no do electrão são raios-X. O que me faz constantemente voltar a Grenoble é um sincrotrão, em que os electrões dão voltas de 600 metros e emitem raios- $X$ a cada curva: o European Synchrotron Radiation Facility (Figura 2).

$\mathrm{O}$ que ponho à frente desse feixe de raios- $X$ de alta intensidade são cristais de proteína. Um cristal é um sólido em que as moléculas estão todas orientadas da mesma maneira. Assim, quando a radiação incide no cristal todas as moléculas interagem com ela da mesma maneira. Se as moléculas estivessem cada uma virada para seu lado, a interacção de uma era anulada pela de outra, e no final não víamos nada. É o que acontece com um sólido amorfo.

Fazendo curta a história, pomos o cristal de proteína à frente do feixe de raios-X e parte da radiação é desviada em direcções muito definidas que são registadas num detector (semeIhante a um CCD de uma máquina fotográfica digital). Na imagem obtida no detector aparecem uns pontinhos.
Rodamos o cristal, incidimos mais raios-X e obtemos mais pontinhos. Por inacreditável que pareça, esses pontinhos têm informação sobre a estrutura (a forma em três dimensões) da proteína (a unidade que se repete no cristal).

\section{O Mundo a 173 Graus Negativos}

É um certo paradoxo, a razão pela qual nos damos ao trabalho de arrefecer cristais de proteína antes de os expor a um feixe de raios-X de alta intensidade.

Quanto mais intenso é o feixe de raios- $X$, mais detalhes conseguimos saber da estrutura da proteína que constitui o cristal. Mas o feixe de raios- $X$ também vai destruindo o cristal. Para contornar este paradoxo, fazemos as experiências a 173 graus negativos. Porque a esta temperatura (obtida graças a uma corrente constante de ar seco, arrefecido com azoto líquido) tudo é mais lento, nomeadamente os estragos por radiação.

Cada cristal é pescado da gota em que cresce, com um laço muito pequeno (semelhante a um laço à cowboy, com algumas décimas de milímetro) e mergulhado em azoto líquido. Mas antes, como um cristal de proteína tem cerca de $50 \%$ de água, temos que a tirar lá de dentro. Senão acontece o mesmo que a uma garrafa de água cheia que se coloca no congelador: aumenta de volume e parte. Substituímos a água no cristal por outro líquido que não aumente de volume quando congela. Em geral, glicerol (tem de ser uma molécula pequena, para poder entrar nos canais de solvente do cristal).

Pescamos o cristal, mergulhamos em azoto líquido, enroscamos a base do laço à cowboy num pequeno tubo de plástico e guardamos. A partir de aqui, tudo tem que ser feito num banho de azoto líquido.

Encaixar e desencaixar a base magnética, colocar o tubinho num carrossel para poder ser medido, encaixá-lo numa peça de metal para ser transportado num termo em azoto líquido. Usam-se pinças e varinhas magnéticas para fazer estas operações. Porque não podemos simplesmente pegar na tampa do frasquinho e desenroscá-la com os dedos mergulhados em azoto líquido (Figura 3). 


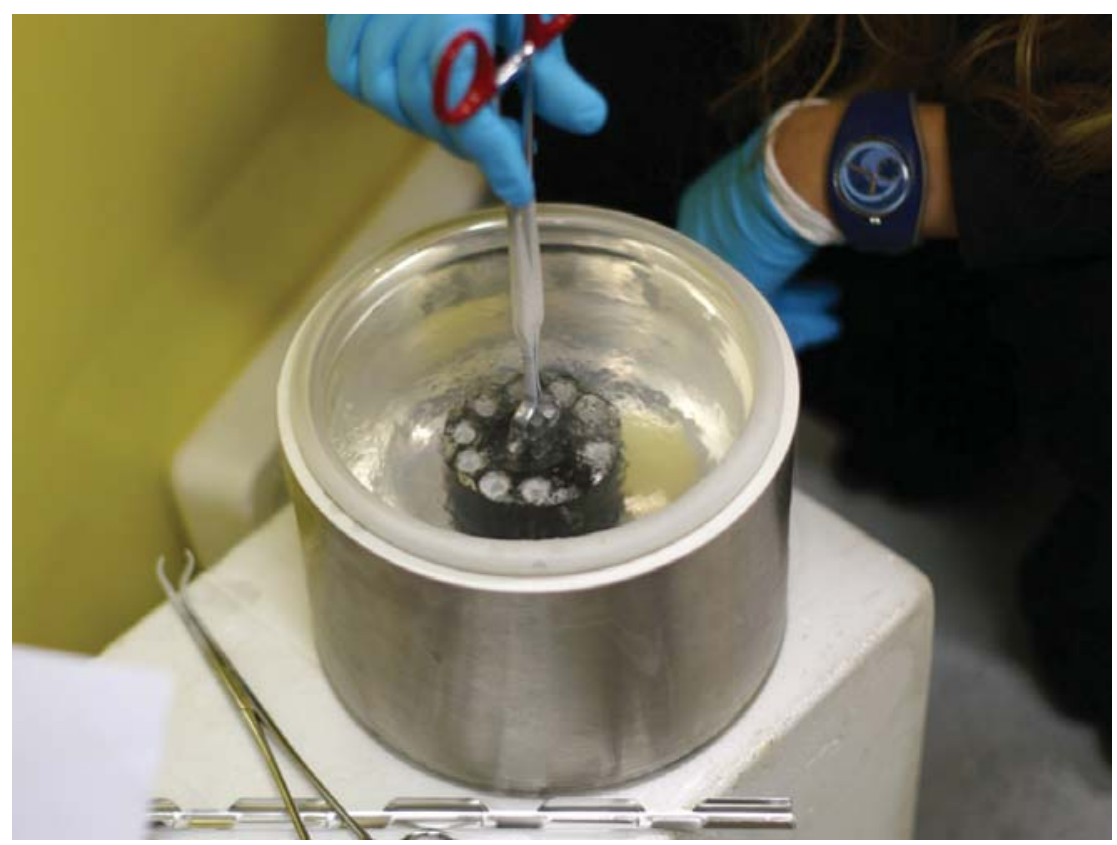

Figura 3 - Operações triviais à temperatura ambiente passam a requerer uma certa técnica e cuidado, para não descongelarmos o cristal e não nos queimarmos com o azoto líquido

\section{A Paragem Sem Assento}

Na semana seguinte à defesa da tese voltei ao acelerador de partículas de Grenoble para recolher dados, uma espécie de digressão de despedida ou viagem de finalistas (mas ocorreume que para uma viagem de finalistas do doutoramento, uma vez que não tive propriamente uma turma, deveria ter ido sozinho).

Ao longo do ano seguinte ainda haveria de escrever artigos sobre o trabalho em que andei envolvido. Duas semanas depois já tinha agendadas reuniões por causa dos meus próximos projectos, mais ligados à comunicação de ciência. No fim de contas, o doutoramento foi só uma paragem e mal tive tempo de dizer cheguei antes de me por de novo a andar.

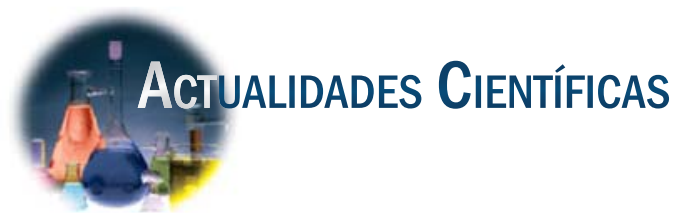

\section{Novo Método Detecta Compostos Tóxicos de Arsénio}

Investigadores da Universidade de Alberta, no Canadá, desenvolveram uma nova técnica analítica para a detecção de um composto de arsénio tóxico, que se tem revelado particularmente difícil de medir (Environ. Sci. Technol., DOI: 10.1021/es100273b). Com este novo método, os cientistas esperam descobrir que estes químicos contaminam mais aquíferos do que anteriormente pensado.

A toxicidade dos compostos de arsénio pode variar de algumas ordens de magnitude. Assim, a simples detecção do elemento não é suficiente para a compreensão do impacto do local contaminado na saúde humana. Infelizmente, os investigadores têm deparado com dificuldades na detecção de um dos compostos de arsénio mais tóxicos, $\mathrm{CH}_{3} \mathrm{As}(\mathrm{OH})_{2}$, ácido monometilarsonoso (MMAIII). Este composto particularmente perigoso, ilude frequentemente a detecção por espectroscopia de massa, já que se revela demasiado estável e não ioniza sobre condições normais. O químico da Universidade de Alberta X. Chris Le, que se dedica ao estudo da detecção de quantidades residuais de elementos tóxicos em sistemas biológicos e ambientais, e seus colaboradores, encontraram uma solução para o problema. De forma a promover a ionização da molécula, a equipa adicionou ácido dimercaptosuccínico às amostras de forma a adicionar uma carga negativa ao MMAIII. Le e colegas puderam posteriormente utilizar espectroscopia de massa em tandem para caracterizar definitivamente o composto tóxico de arsénio.

Os investigadores aplicaram a nova técnica para medir os níveis de MMAIII junto a uma unidade industrial no Wisconsin, que produziu herbicidas contendo arsénio no período de 1957 a 1977. Deste modo, testaram 60 amostras provenientes de aquíferos e encontraram valores para a concentração de contaminante que variavam desde $3.9 \mathrm{mg} / \mathrm{L}$ até $274 \mathrm{mg} / \mathrm{L}$. Estas concentrações são 1000 vezes mais elevadas do que a referência definida pela Environmental Protection Agency para águas potáveis, e aproximadamente um milhão de vezes maiores que as concentrações de MMAIII previamente reportadas na literatura (Appl. Organomet. Chem. 1997, 11, 305).
Le supõe que os químicos redutores provenientes da fábrica de herbicidas penetraram o solo ao redor da fábrica. Assim, as condições ambientais não controladas do local podem ter conduzido à produção desta abundância de MMAIII. Le afirma que "estas condições redutoras podem existir noutros locais e é possível que os investigadores encontrem altos níveis de MMAIII em outros tipos de sítios para além da vizinhança de fábricas de herbicidas". Este novo método de detecção "abre novas oportunidades na investigação do arsénio ambiental" afirma Ronald S. Oremland do U.S. Geological Survey, em Menlo Park, Califórnia. "Apesar das concentrações de MMAIII detectadas neste local particular representarem provavelmente um caso extremo do que é possível detectar, estes dados frisam a importância de uma monitorização mais rigorosa dos compostos metilados de arsénio no ambiente".

(Adaptado do artigo de 12/07/2010 de David Pittman: New Method Detects Particularly Toxic Arsenic Compound Chemical \& Engineering News, http://pubs.acs. org/cen/news/88/i29/8829news1.html) 